\section{Alfentanil-midazolam anaesthesia has no electrophysiological effects upon the normal conduction system or accessory pathways in patients with Wolff-Parkinson-White syndrome}

The effects of alfentanil-midazolam anaesthesia upon the electrophysiologic $(E P)$ properties of normal atrioventricular $(A-V)$ and accessory pathway (AP) conduction were studied in eight patients with Wolff-Parkinson-White syndrome during accessory pathway surgical ablation. The presence of an $A P$ was confirmed by preoperative EP studies. Anaesthesia was induced with alfentanil $\left(50 \mu \mathrm{g} \cdot \mathrm{kg}^{-1}\right)$ and midazolam $\left(0.15 \mathrm{mg} \cdot \mathrm{kg}^{-1}\right)$ and maintained with an alfentanil infusion $\left(2 \mu \mathrm{g} \cdot \mathrm{kg}^{-1} \cdot \mathrm{min}^{-1}\right)$ and intermittent boluses of midazolam (1-2 mg q $15 \mathrm{~min}, P R N)$. Following stemotomy, a baseline EP study was performed which consisted of effective refractory period (ERP) and shortest cycle length (SCC) measurement during antegrade conduction in the $A V$ and $A P$, as well as during retrograde conduction in the $A P$. Comparison with preoperative EP studies indicated that the administration of alfentanil-midazolam anaesthesia had no effect upon conduction or ERP in either pathway. Haemodynamic stability occurred throughout the surgical procedure with no

\section{Key words}

ANAESTHETICS, INTRAVENOUS: alfentanil, midazolam; HEART: arrhythmia, Wolff-Parkinson-White, conduction.

From the Departments of Anaesthesia*, Cardiology $\dagger$ and Cardiovascular Surgery $\ddagger$, University Hospital, University of Western Ontario, London, Ontario N6A 5A5.

Address correspondence to: Dr. M.D. Sharpe, Department of Anaesthesia, University Hospital, P.O. Box 5339, London, Ontario N6A 5A5.

Presented in part at the Canadian Anaesthetists' Society Annual Meeting, Quebec 1991.

Accepted for publication 14th June, 1992.
Michael D. Sharpe MD FRCPC,*

Wojciech B. Dobkowski MD FRCPC,*

John M. Murkin MD FRCPC, ${ }^{*}$ George Klein MD FRCPC, $\dagger$ Gerard Guiraudon MD FRCSC, $\ddagger$ Raymond Yee MD FRCPC $\dagger$ tachyarrhythmias. We conclude that a combination of alfentanilmidazolam is suitable for general anaesthesia in patients undergoing ablative procedures for accessory pathways.

Les effets de l'anesthésie à l'alfentanil-midazolam sur les propriétés électrophysiologiques de la voie de transmission atrioventriculaire normale et accessoire sont étudiés chez huit porteurs du syndrome de Wolff-Parkinson-White pendantl'ablation chirurgicale du réseau accessoire. On avait au préalable confirmé la présence d'une voie de conduction accessoire par des études électrophysiologiques pré-opératoires. L'anesthésie est induite avec de l'alfentanil ( $\left.50 \mu \mathrm{g} \cdot \mathrm{kg}^{-1}\right)$ et du midazolam $\left(0,15 \mathrm{mg} \cdot \mathrm{kg}^{-1}\right)$ et maintenue avec une perfusion d'alfentanil (2 $\left.\mu \mathrm{g} \cdot \mathrm{kg}^{-1}\right)$ et des bolus intermittents de midazolam (1-2 mg q 15 min, PRN). Après la sternotomie, on réalise une étude électrophysiologique de base portant sur la période réfractaire efficace et la mesure de la longueur du cycle le plus court pendant la conduction antégrade pour les voies normale et acessoire, ainsi que pendant la conduction rétrograde pour la voie accessoire. La comparaison avec les études électrophysiologiques pré-opératoires montre que l'anesthésie à l'alfentanil-midazolam n'a d'influence ni sur la conduction, ni sur la période réfractaire efficace de l'une ou l'autre des voies de transmission. Les paramètres hémo-dynamiques demeurent stables et sans tachyarythmies pendant toute la durée de l'intervention. Nous en concluons que l'association alfentanilmidazolam est une technique anes-thésique acceptable pour l'ablation chirurgicale des voies de conduction aberrantes.

Advances in the understanding of the electrophysiology of pathological accessory atrioventricular pathways (AP) in 
patients with pre-excitation syndromes, has led to the development of ablative procedures using both surgical and non-surgical techniques. ${ }^{1-3}$ Although the recent development of AP ablation using radiofrequency energy has precluded the requirement for surgery in most cases, patients failing this technique may require sternotomy and surgical ablation under general anaesthesia. ${ }^{46}$ Successful anaesthetic management of these patients includes the suppression of sympathetic stimulation in response to perioperative stimuli while allowing normal physiological expression of the accessory pathway and the normal atrioventricular conduction system to facilitate mapping. ${ }^{7,8}$

Various animal models have been used to measure the effects of anaesthetic agents upon conduction in the normal A-V conducting system but an animal model of a pathological accessory pathway does not exist. ${ }^{9.10}$ Inhalational anaesthetics (enflurane, halothane, isoflurane) have been shown to depress conduction in both the normal and AP conducting systems, but no data exist regarding the effects of alfentanil and midazolam upon conduction in animals or humans. ${ }^{11-13}$ Therefore, we studied the effect of general anaesthesia, using a combination of alfentanil and midazolam, upon the electrophysiological properties of the normal $\mathrm{A}-\mathrm{V}$ conduction system and $\mathrm{AP}$, in a group of patients with Wolff-Parkinson-White Syndrome (WPW), undergoing surgical ablation of the accessory pathways.

\section{Methods}

With Ethics Committee approval and signed patient consent, eight patients (six men and two women, ASA II) with WPW syndrome were studied. No other concomitant diseases were present. The identification and localization (mapping) of a single or multiple pathological accessory pathway had been confirmed by an electrophysiological (EP) study previously performed using transvenous endocardial electrodes in the EP laboratory. The EP study protocol included: (1) right atrial refractory period determination at cycle lengths of 400 and $500 \mathrm{msec}$ (including right atrial effective refractory (RAERP), AV node effective refractory period (AVNERP), and accessory pathway effective refractory period (APERP)), coupling intervals were in steps of $20 \mathrm{msec}$ from 300 to $400 \mathrm{msec}$ and in steps of $10 \mathrm{msec}$ below $300 \mathrm{msec}$, (2) right ventricular effective refractory period (RVERP) at a cycle length of $400 \mathrm{msec}$, (3) shortest cycle length (SCL), also known as the Wenckebach cycle length (WBCL), with 1:1 conduction over the normal AV node (SCL-AVN) and accessory (SCL-AP) pathway. A definition of each of these variables is provided in Table $I$.

On the day of surgery, patients received pre-medication with lorazepam $\left(0.06 \mathrm{mg} \cdot \mathrm{kg}^{-1}, \mathrm{sl}\right)$. Anaesthesia was induced with alfentanil $50 \mu \mathrm{g} \cdot \mathrm{kg}^{-1}$, midazolam 0.15 $\mathrm{mg} \cdot \mathrm{kg}^{-1} i v$, and tracheal intubation was facilitated with
TABLE I Definition of terms

\begin{tabular}{|c|c|}
\hline Term & Definition \\
\hline ERP & $\begin{array}{l}\text { Effective refractory period of cardiac tissue is the } \\
\text { longest coupling interval between the basic drive and } \\
\text { the premature impulse that fails to propagate through } \\
\text { that tissue. }\end{array}$ \\
\hline RAERP & $\begin{array}{l}\text { Right atrial effective refractory period - the longest } \\
\text { interval between the two impulses that fails to stimu- } \\
\text { late the atrium (to result in atrial depolarization). }\end{array}$ \\
\hline AVNERP & $\begin{array}{l}\text { Atrioventricular node effective refractory period - the } \\
\text { longest coupling interval between two atrial impulses } \\
\text { that fails to conduct over the AV node. }\end{array}$ \\
\hline APERP & $\begin{array}{l}\text { Accessory pathway effective refractory period - the } \\
\text { longest interval between two impulses that fails to } \\
\text { conduct through accessory pathway (to result in AP } \\
\text { depolarization). }\end{array}$ \\
\hline $\begin{array}{l}\text { WBCL } \\
\text { or } \\
\text { SCL-AVN } \\
\text { SCL-AP }\end{array}$ & $\begin{array}{l}\text { Wenckebach cycle length or shortest cycle length of } \\
\text { the atrioventrcular node or accessory pathway, with } \\
1: 1 \text { conduction - the shortest interval or the fastest } \\
\text { rate at which the AV node/accessory pathway can } \\
\text { conduct anterogradely or retrogradely prior to } \\
\text { Wenckebach block. }\end{array}$ \\
\hline
\end{tabular}

vecuronium $20 \mathrm{mg}$, iv. Anaesthesia was maintained with a continuous infusion of alfentanil $2 \mu \mathrm{g} \cdot \mathrm{kg}^{-1} \cdot \mathrm{min}^{-1}$ and intermittent doses of midazolam (1-2 mg, iv) every 15 min, as required. Positive pressure ventilation with airoxygen was used to maintain normocapnia and arterial oxygen saturation greater than $96 \%$ (Nellcor Capnograph/ Oximeter). Other monitors included a radial arterial line, central venous pressure (CVP) catheter and a nasopharyngeal temperature probe.

After sternotomy, an EP study was performed and recorded using epicardial hexipolar surface electrodes (two stimulating and four recording electrodes) sutured to the right atrium and right ventricle for bipolar pacing and recording. ${ }^{11-13}$

For statistical analysis, comparison of the baseline EP study with the EP study performed during alfentanilmidazolam anaesthesia, as well as comparison of haemodynamic variables, arterial blood gas analysis, temperature, PETCO ${ }_{2}$, sodium $\left(\mathrm{Na}^{++}\right)$, potassium $\left(\mathrm{K}^{+}\right)$, calcium $\left(\mathrm{Ca}^{++}\right)$, and magnesium $\left(\mathrm{Mg}^{++}\right)$measured prior to and following induction of anaesthesia, were made using paired Student's t tests. The results are expressed as mean $\pm \mathrm{SD} . P<0.05$ was considered statistically significant.

\section{Results}

The anthropometric characteristics of the eight subjects are shown in Table II. Haemodynamic variables including systolic, diastolic, mean arterial and central venous pressures were similar before and after the induction of alfentanil-midazolam anaesthesia (Table III), although there was a tendency for arterial blood pressure to decrease 
TABLE II Anthropometric characteristics

\begin{tabular}{lll}
\hline & Mean $\pm S D$ & Range \\
\hline Age $(\mathrm{yr})$ & $28 \pm 6$ & $20-38$ \\
Weight $(\mathrm{kg})$ & $66 \pm 5$ & $59-74$ \\
\hline
\end{tabular}

TABLE III Effect of alfentanil-midazolam anaesthesia on haemodynamic variables

\begin{tabular}{lcc}
\hline & Pre-induction & Post-induction \\
\hline SAP (mmHg) & $128 \pm 18$ & $116 \pm 22$ \\
DAP (mmHg) & $78 \pm 14$ & $66 \pm 8$ \\
MAP (mmHg) & $84 \pm 10$ & $72 \pm 12$ \\
CVP (mmHg) & $8 \pm 2$ & $10 \pm 04$ \\
\hline
\end{tabular}

Mean \pm SD

TABLE IV Effect of alfentanil-midazolam anaesthesia on arterial blood gas analysis, temperature, $\mathrm{PETCO}_{2}$, electrolytes

\begin{tabular}{lcc}
\hline & Pre-induction & Post-induction \\
\hline $\mathrm{PO}_{2}(\mathrm{mmHg})$ & $248 \pm 16^{*}$ & $256 \pm 22$ \\
$\mathrm{PCO}_{2}(\mathrm{mmHg})$ & $36 \pm 2$ & $35 \pm 1$ \\
$\mathrm{pH}$ & $7.38 \pm 0.02$ & $7.36 \pm 0.02$ \\
$\mathrm{~T}\left({ }^{\circ} \mathrm{C}\right)$ & $36.4 \pm 0.2$ & $36.1 \pm 0.3$ \\
$\mathrm{PETCO}_{2}(\mathrm{mmHg})$ & $36 \pm 3$ & $35 \pm 3$ \\
$\left.\mathrm{~K}^{+} \mathrm{mg} \cdot \mathrm{dL}^{-1}\right)$ & $4.5 \pm 0.2$ & $4.3 \pm 0.3$ \\
$\mathrm{Na}^{+}\left(\mathrm{mg} \cdot \mathrm{dL}^{-1}\right)$ & $138 \pm 2$ & $137 \pm 1$ \\
$\mathrm{Ca}^{++}\left(\mathrm{mg} \cdot \mathrm{dL}^{-1}\right)$ & $4.3 \pm 0-3$ & $4.2 \pm 0.2$ \\
$\mathrm{Mg}^{++}\left(\mathrm{mg} \cdot \mathrm{dL}^{-1}\right)$ & $1.5 \pm 0.1$ & $1.6 \pm 0.2$ \\
\hline
\end{tabular}

Mean \pm SD

*Oxygen supplementation by mask before induction of anaesthesia.

with induction of anaesthesia. EP studies began approximately 20-30 min postinduction and there was no change in heart rate or arterial blood pressure in response to surgical stimuli during this period. Arterial blood gas analysis, temperature, $\mathrm{PETCO}, \mathrm{K}^{+}, \mathrm{Na}^{+} \mathrm{Ca}^{++}$, and $\mathrm{Mg}^{++}$ were within normal limits, and did not change with induction of anaesthesia (Table IV). $\mathrm{PETCO}_{2}$ and oxygen saturation (pulse oximetry) remained constant throughout the procedure.

Comparison of EP studies performed preoperatively and following induction of alfentanil-midazolam anaesthesia showed no detectable difference in conduction or refractory periods in the normal $\mathrm{A}-\mathrm{V}$ conduction system during anterograde conduction, or in the accessory pathway during antegrade and retrograde conduction (Table V). Accordingly, since our data suggests the possibility of alfentanil-midazolam as having no effect, we examined our results post-hoc for the probability of a type II error. Specifically, we tested for the probability of failure to detect a $20 \%$ difference using the power of a test of significance equation ${ }^{14}$ since changes of this magnitude are not clinically important. The calculated beta value was $<0.06$.
TABLE V Effect of alfentanil-midazolam anaesthesia on conduction of the normal A-V system and accessory pathway (AP)

\begin{tabular}{lcll}
\hline & $n$ & $\begin{array}{l}\text { Control } \\
(\mathrm{msec})\end{array}$ & $\begin{array}{l}\text { ALF-MID } \\
(\mathrm{msec})\end{array}$ \\
\hline $\begin{array}{l}\text { Antegrade } \\
\text { RAERP }\end{array}$ & 8 & $215 \pm 18$ & $209 \pm 21$ \\
AVNERP & 8 & $264 \pm 24$ & $250 \pm 19$ \\
APERP & 8 & $322 \pm 52$ & $311 \pm 46$ \\
SCL-AP & 8 & $306 \pm 60$ & $312 \pm 50$ \\
Retrograde conduction & & \\
RVERP & 8 & $206 \pm 22$ & $214 \pm 28$ \\
APERP & 6 & $252 \pm 28$ & $238 \pm 30$ \\
SCL-AP & 7 & $304 \pm 66$ & $288 \pm 54$ \\
\hline
\end{tabular}

Mean $\pm S D, A L F=$ alfentanil, $M I D=$ midazolam.

Therefore, we conclude a difference in conduction variables $\geqslant 20 \%$ was not present during alfentanil-midazolam administration.

All accessory pathways were successfully identified and surgically ablated. As well, no tachyarrhythmias occurred during general anaesthesia other than those induced during the EP study.

\section{Discussion}

The criteria for an optimal anaesthetic administered for ablative procedures for pathological accessory pathways include: (i) minimal effect by anaesthetic agents on conduction in either the normal A-V conduction system or in the accessory pathway(s) and (ii) adequate suppression of the sympathetic response to induction, intubation and surgical stimulation. Our results show that a combination of alfentanil and midazolam had no effect upon conduction in either the normal $\mathrm{A}-\mathrm{V}$ conduction system or in the accessory pathways and, as well, adequately suppressed any haemodynamic response to surgery.

The WPW syndrome is the most common pre-excitation syndrome and is characterized by an accessory pathway between the atrium and ventricle located in the $A-V$ sulcus. This anomalous bypass tract shares characteristics of normal myocardial fibres and is capable of transmitting impulses in both an antegrade and retrograde direction, at very high rates. ${ }^{15}$ The most common tachyarrhythmias associated with WPW are atrioventricular reentrant or atrial fibrillation, or both, with a fast ventricular response due to rapid conduction over the AP tract. Therefore, any perioperative stress resulting in sympathetic stimulation may potentially precipitate atrial fibrillation or supraventricular tachycardia resulting in a rapid ventricular response.

The absence of effect of alfentanil-midazolam on the electrophysiological properties of normal and AP conducting tissue is an important characteristic for any anaesthetic 
agent that would be utilized during ablative procedures. For example, we have shown that the inhalational agents halothane, isoflurane and enflurane depress conduction in both the normal A-V conduction system and accessory pathway. ${ }^{11-13}$ Therefore, the use of these agents or any agent that is capable of depressing conduction in either pathway may make identification of the accessory pathway difficult and jeopardize the ablation procedure.

It is also important not to alter the electrophysiological milieu. Electrical transmission over the AP depends on sodium-dependent fast-inward current, whereas the AV node utilizes a calcium-dependent slow-inward current. Any changes in plasma concentration of these ions, as well as $\mathrm{K}^{+}$and $\mathrm{Mg}^{++}$and thus transmembrane gradients, or changes in ion concentration due to $\mathrm{pH}$ changes, may have considerable impact upon transmission in either pathway. ${ }^{7.16}$ As anticipated, there were no changes in these variables following induction of anaesthesia (Table IV).

Our study also demonstrated that a $50 \mu \mathrm{g} \cdot \mathrm{kg}^{-1}$ bolus of alfentanil followed by an infusion of $2 \mu \mathrm{g} \cdot \mathrm{kg}^{-1} \cdot \mathrm{min}^{-1}$ with the concomitant administration of midazolam provided a very stable and sufficient level of anaesthesia throughout the ablative procedure in all patients. It is desirable that the depth of anaesthesia is adequate to suppress any sympathetic response to surgical stimulation to prevent the induction of tachyarrhythmias. In our study, there were no unprovoked incidences of tachyarrhythmia prior to ablation of the accessory pathway. However, there was a tendency for arterial blood pressure to decrease following anaesthetic induction with alfentanil, which would likely attain statistical significance with a larger sample size. Alfentanil shares many of the cardiovascular properties of fentanyl and sufentanil; however, it has been shown to have a greater tendency to produce hypotension, and consequently a higher incidence of ischaemia, in patients -vith coronary artery disease. ${ }^{17}$ Furthermore, DeLange $e t$ al. concluded that alfentanil was less reliable than sufentanil or fentanyl for blocking the sympathetic response to induction, sternotomy, sternal spread or aortotomy in patients undergoing coronary artery bypass grafting. ${ }^{18}$ However, the dosage of alfentanil we employed resulted in a very stable haemodynamic state with minimal sympathetic response to surgical stimuli. In addition, the patient population presenting for ablative procedures is relatively young (Table I), and therefore the presence of coronary artery disease is unlikely. As such, the potential for hypotension to induce myocardial ischaemia in this population is much less of a concern.

The recent development and success of transcatheter ablation via the transvenous route has diminished the need for sternotomy under general anaesthesia to permit surgical ablation. Nonetheless, operative ablation is still necessary in patients who have failed transcatheter ablation due to accessory pathways in anatomical locations difficult to reach.

In our practice this occurs in 5-10\% of cases, consistent with experiences reported elsewhere. ${ }^{5.19 .20}$ It is in this group of patients who present for surgical ablation that knowledge of the effect of anaesthetic agents upon conduction through the normal A-V and AP becomes particularly important. Any substantial effect upon conduction in either pathway, such as with the inhalational anaesthetics, will make the EP mapping more difficult in what is an already challenging case. Other patient populations who may require general anaesthesia for transcatheter ablation are young paediatric patients and adult patients who are agitated. In our experience, most patients are successfully ablated under neuroleptanaesthesia using a combination of midazolam (1-3 mg q15 min, PRN) and alfentanil (500$1000 \mu \mathrm{g} \mathrm{q15-30} \mathrm{min,} \mathrm{PRN).} \mathrm{Patient} \mathrm{compliance} \mathrm{and}$ comfort is much improved with this technique and, at the doses employed, we anticipate no electrophysiological effects of these drugs.

Where general anaesthesia for sternotomy and subsequent surgical ablation is required, midazolam and alfentanil are again our agents of choice. Inhalational anaesthesia should be avoided because of the previously demonstrated depressive effects on both the normal A-V conducting system and accessory pathway. ${ }^{11-13}$ The effect of fentanyl on conduction is controversial. Gómez-Arnau et al. found that fentanyl had no effect on accessory pathway conduction in patients with WPW. ${ }^{21}$ However, a previous study in dogs of the effects of fentanyl on conduction in the normal A-V conduction. sy.stem demonstrated prolongation of AV node conduction, AV node effective and functional refractory periods, and ventricular effective refractory periods, using both low $\left(100 \mu \mathrm{g} \cdot \mathrm{kg}^{-1}\right)$ and high dose (400 $\mu \mathrm{g} \cdot \mathrm{kg}^{-1}$ ) regimens. ${ }^{22}$ Therefore, fentanyl may make induction of atrioventricular reentrant tachycardia difficult and complicate mapping. At present, no data exists regarding the electrophysiological effects of morphine on conduction in AP.

Sufentanil would be an appropriate agent to administer to patients undergoing sternotomy for surgical ablative procedures since we have previously shown it has minimal affect on conduction in either the normal $\mathrm{A}-\mathrm{V}$ conduction system or accessory pathway. ${ }^{23}$ However, alfentanil is a more suitable agent because of its rapid onset and shorter elimination half-life, and therefore, less likely to cause respiratory depression requiring postoperative ventilation. Because of its lipid solubility and volume of distribution, less alfentanil is stored in the brain which explains alfentanil's rapid decline in activity after cessation of drug infusion. ${ }^{24}$ Following an intravenous bolus dose of alfentanil $50 \mu \mathrm{g} \cdot \mathrm{kg}^{-1}$, as used in our study, plasma therapeutic levels $\left(>400 \mathrm{ng} \cdot \mathrm{ml}^{-1}\right)$ will be achieved. ${ }^{25}$ However, unless 
a constant infusion is initiated following the administration of a bolus dose, then plasma concentrations will decrease to below $300 \mathrm{ng} \cdot \mathrm{ml}^{-1}$ within three to five minutes. ${ }^{26}$ As the total amount of alfentanil administered is increased, its termination of action will become more dependent upon elimination rather than redistribution. From our experience, we terminated the infusion approximately $20 \mathrm{~min}$ before the end of the procedure, which resulted in the patients breathing spontaneously and waking appropriately. No patients required postoperative ventilation or naloxone administration. Under usual circumstances, spontaneous ventilation will occur with serum levels of alfentanil less than $200 \mathrm{ng} \cdot \mathrm{ml}^{-1} \cdot{ }^{27}$

In conclusion, our study demonstrates that the administration of alfentanil and midazolam has no effect upon conduction in either the normal A-V conduction system or accessory pathways in patients with WPW. Furthermore, this combination proved to be a very reliable and haemodynamically stable anaesthetic. It is very suitable for anaesthesia in patients undergoing ablative procedures for accessory pathways.

\section{References}

1 Guiraudon GM, Klein GJ, Sharma AD, Jones $D L$, McLellan DG. Surgery for Wolff-Parkinson-White Syndrome: further experience with a closed heart technique. Circulation 1986; 74: 525-9.

2 Guiraudon GM, Klein GJ, Sharma AD, Milstein S, McLellan DG. Closed-heart technique for Wolff-Parkinson-White Syndrome: further experience and potential limitations. Ann Thorac Surg 1986; 42: 651-7.

3 Guiraudon GM, Klein GJ, Jones D, Kerr CR. Surgical treatment of Wolff-Parkinson-White Syndrome. Can J Surg 1983; 26: 147-9.

4 Warin JF, Haissaguerre M, Lemetayer P, Guillem JF, Blanchot $P$. Catheter ablation of accessory pathways with a direct approach. Results in 35 patients. Circulation 1988; 78: 800-15.

5 Leather RA, Leitch JW, Klein GJ, Guiraudon GM, Yee R, Kim $Y H$. Radiofrequency catheter ablation of accessory pathways: a learning experience. Am J Cardiol 1991; 68: 1651-5.

6 Selle JG, Svenson RH, Sealy WC. Successful clinical laser ablation of ventricular tachycardias: a promising new therapeutic method. Ann Thorac Surg 1986; 42: 380-4.

7 Lubarsky D, Kaufman B, Turndorf H. Anesthesia unmasking benign Wolff-Parkinson-White Syndrome. Anesth Analg 1989; 68: 172-4.

8 Sadowski AR, Moyers JR. Anesthetic management of the Wolff-Parkinson-White Syndrome. Anesthesiology 1979; 51: 553-6.

9 Lynch III C, Vogel S, Sperelakis N. Halothane depression of myocardial slow action potentials. Anesthesiology 1981; 55: 360-8.

10 Atlee $J L$, Brownlee SW, Burstrom RE. Conscious-state comparisons of the effects of inhalation anesthetics on specialized atrioventricular conduction times in dogs. Anesthesiology 1986; 64: 703-10.

11 Dobkowski WB, Murkin JM, Sharpe MD, Molotiu N, Guiraudon $G$, Yee $R$. The effect of enflurane (1 MAC) on the normal AV conduction system and accessory pathways. Anesth Analg 1991; 72: S50.

12 Dobkowski WB, Murkin JM, Sharpe MD, Sharma AD, Yee $R$, Guiraudon $G$. The effect of isoflurane (1 MAC) on the normal AV conduction system and accessory pathways. Anesth Analg 1990; 70: S86.

13 Sharpe MD, Murkin JM, Dobkowski WB, et al. Halothane depresses conduction of normal and accessory pathways during surgery for Wolff-Parkinson-White Syndrome. Anesth Analg 1990; 70: S365.

14 Snedecor GW, Cochran WG. Statistical methods. 7th ed. Iowa: The Iowa State University Press, 1980; 68-70.

15 Guiraudon GM, Klein GJ, Sharma AD, Yee R. Surgical alternatives for supraventricular tachycardias. Am J Cardiol 1989; 64: 92J-96J.

16 Atlee JL, Bosnjak ZJ. Mechanisms for cardiac dysrhythmias during anesthesia. Anesthesiology 1990; 72 : 347-74.

17 Miller DR, Wellwood M, Teasdale SJ, et al. Effects of anaesthetic induction on myocardial function and metabolism: a comparison of fentanyl, sufentanil and alfentanil. Can J Anaesth 1988; 35: 219-33.

18 De Lange S, Stanley $T h$, Boscoe MJ. Afentanil-oxygen anaesthesia for coronary artery surgery. $\mathrm{Br} J$ Anaesth $1981 ; 53: 1291-6$.

19 Calkins $H$, Sousa J, El-Atassi $R$, et al. Diagnosis and cure of the Wolff-Parkinson-White syndrome or paroxysmal ventricular tachycardias during a single electrophysiologic test. N Engl J Med 1991; 324: 1612-8.

20 Jackman WM, Wang X, Friday KJ, et al. Catheter ablation of accessory atrioventricular pathways (WolffParkinson-White syndrome) by radiofrequency current. N Engl J Med 1991; 324: 1605-11.

21 Gómez-Arnau J, Márques-Montes J, Avello F. Fentanyl and droperidol effects on the refractoriness of the accessory pathway in the Wolf-Parkinson-White Syndrome. Anesthesiology 1983; 58: 307-13.

22 Royster RL, Keeler DK, Haisty WK, Johnston WE, Prough $D S$. Cardiac electrophysiologic effects of fentanyl and combinations of fentanyl and neuromuscular relaxants in pentobarbitol-anesthetized dogs. Anesth Analg 1988; 67: 15-20.

23 Sharpe MD, Murkin JM, Dobkowski WB, et al. Sufentanil anaesthesia has no effect on conduction of normal and 
accessory pathways in patients with Wolff-ParkinsonWhite Syndrome. Anesth Analg 1991; 72: S248.

24 Scott JC, Ponganis KV, Stanski DR. EEG quantitation of narcotic effect: the comparative pharmacodynamics of fentanyl and alfentanil. Anesthesiology 1985; 62: 234-41.

25 Fragen RJ, Booij LHDJ, Braak GJJ, Vree TB, Heykants J, Crul JF. Pharmacokinetics of the infusion of alfentanil in man. Br J Anaesth 1983; 55: 1077-81.

26 Bovill JG, Sebel PS, Blackburn CL, Heykants J. The pharmacokinetics of alfentanil (R39209): a new opioid analgesic. Anesthesiology 1982; 57: 439-43.

27 Stanski $D R$, Hug Jr CC. Alfentanil - a kinetically predictable narcotic analgesic. Anesthesiology 1982; 57: 435-8. 